PRZEGLĄD NAUK HISTORYCZNYCH 2016, R. XV, NR 1

http://dx.doi.org/10.18778/1644-857X.15.01.04

ADRIAN ULJASZ

(UniWERSYTET RZESZOWSKI) ${ }^{*}$

\title{
Z dziejów prasy lokalnej w II Rzeczypospolitej Żydowski „Przegląd Rzeszowski” z 1927 i 1932 roku
}

Streszczenie. „Przegląd Rzeszowski” z 1927 i 1932 r. to żydowskie pisma w języku polskim, wychodzące w Rzeszowie. „Przegląd Rzeszowski” z 1927 r. był dwutygodnikiem, a „Przegląd Rzeszowski” z 1932 r. tygodnikiem. W 1927 r. funkcję redaktorów pełnili C.L. Platzer i M.M. Fröchlich. Redaktorem naczelnym „Przeglądu Rzeszowskiego" z 1932 r. był Samuel Lubasz. W obu czasopismach omawiano zagadnienia ekonomiczne, socjalne i polityczne dotyczące Żydów. Informowano o wydarzeniach w mieście i regionie. Popularyzowano żydowskie życie kulturalne i sportowe. Ogłaszano reklamy.

Słowa kluczowe: „Przegląd Rzeszowski” 1927, „Przegląd Rzeszowski” 1932, historia prasy, historia Żydów, historia Rzeszowa.

T stotne znaczenie w dziejach prasy maja czasopisma regionalne i lokalne jako wpływające na świadomość dużej części mieszkańców państwa. Odbiorcy szczególnie często czytali takie periodyki. Redaktorzy tytułów skierowanych do mieszkańców regionu lub miasta w dużym stopniu kształtowali świadomość czytelników. Współcześnie archiwalne roczniki stanowią cenne źródło wiedzy o dziejach terenu, którego dotyczą.

Wśród pism lokalnych zwraca uwage prasa adresowana do mniejszości narodowych, interesująca $z$ punktu widzenia dziejów danej grupy mniejszościowej oraz historii poszczególnych miast. $\mathrm{Na}$ udokumentowanie zasługuje przykład $z$ terenu Rzeszowa - dwa żydowskie czasopisma w języku polskim, zatytułowane „Przegląd

\footnotetext{
* Wydział Socjologiczno-Historyczny, Instytut Historii, Zakład Kulturoznawstwa.
} 
Rzeszowski", ukazujące się w 1927 i 1932 r. Oba pisma dotąd nie stały się obiektem badań prasoznawczych ${ }^{1}$. Historycy bardzo nielicznie cytowali teksty z obu periodyków, głównie artykuł z 1932 r. odnoszacy się do handlu ulicznego ${ }^{2}$.

W czasach II RP Żydzi stanowili dużą część ludności Rzeszowa, znajdującego się wówczas na podstawie ustawy z 3 grudnia $1920 \mathrm{r}$. na terenie województwa lwowskiego. Zgodnie ze spisem powszechnym z 1931 r. było to 11228 osób - 41,7\% mieszkańców miasta. Większość lokalnej społeczności żydowskiej wykonywała zawody robotnicze. Jej liczni członkowie należeli do drobnomieszczaństwa. Główne dziedziny zarobkowania rzeszowskich Żydów to handel, przemysł i rzemiosło. Wiele osób pracowało jako adwokaci i lekarze. Mniejszość żydowska wykazywała się dużą aktywnością we władzach samorządowych. Miała własny klub radnych w radzie miasta. W 1934 r. 15 radnych spośród jej 35-osobowego składu było Żydami. Funkcję zastępcy burmistrza wiele razy pełnił reprezentant Żydów - mecenas Wilhelm Hochfeld.

${ }^{1}$ Odbiorcy artykułu, zainteresowani wiedzą o prasie polskiej i żydowskiej, w tym regionalnej i lokalnej, ukazującej się w II RP, winni sięgnąc m.in. po następujace opracowania: A. Paczkowski, Prasa polska w latach 1918-1939, Warszawa 1980, passim (informacje na temat czasopism żydowskich: s. 349-354. Autor podkreśla, że „Żydowska grupa narodowa miała najliczniejszą prasę spośród wszystkich mniejszości zamieszkujących Polskę i pozycję tę utrzymała do końca II Rzeczypospolitej”, ibidem, s. 349); id e m, Prasa codzienna Warszawy $w$ latach 1918-1939, Warszawa 1983, passim (fragment poświęcony warszawskim dziennikom żydowskim: s. 239-251); U. J a k u b o w s ka, Oblicze ideowo-polityczne „Gazety Warszawskiej” i „Warszawskiego Dziennika Narodowego” w latach 1918-1939, Warszawa 1984, passim (o stosunku „Gazety Warszawskiej” do mniejszości narodowych, m.in. do Żydów: s. 115-135); T. Mielczarek, Prasa w systemie politycznym Drugiej Rzeczypospolitej (1918-1939), Sosnowiec 2009, passim; idem, Od „Monitora” do „Gońca Reklamowego”. Dzieje prasy częstochowskiej (1769-1944), passim (podrozdział na temat lokalnej częstochowskiej „żydowskiej prasy informacyjnej i politycznej” z czasów Drugiej Rzeczypospolitej: s. 91-94). Dzięki lekturze czytelnicy uzyskają tło porównawcze, obraz prasy żydowskiej, wychodzącej w naszym kraju, zarysowany na tle innych czasopism.

${ }^{2}$ Por. W. Wierzbieniec, Żydzi $w$ województwie lwowskim $w$ okresie międzywojennym. Zagadnienia demograficzne i społeczne, Rzeszów 2003, s. 181-182; A. Potocki, Żydzi w Podkarpackiem, Rzeszów 2004, s. 160; Straganiarze, PR, 1932, nr 4, s. 1-2 (artykuł cytowany w naukowym opracowaniu Wacława Wierzbieńca i w popularnonaukowej książce Andrzeja Potockiego). Dwa teksty, jeden z 1927 i jeden z 1932 r., zacytowała Maria E. Ożóg, podając numery pisma, ale nie przekazujacc informacji o numerach stron. Powołując się na artykuł $z \mathrm{nr} 1$ z 1927 r., poinformowała błędnie w tekście głównym swej publikacji i w przypisie, że pismo wychodziło w 1928 r. M.E. Ożóg, Środowisko żydowskie, [w:] Dzieje Rzeszowa, t. III (Rzeszów w okresie międzywojennym i okupacji [1918-1944]), red. F. Kiryk, Rzeszów 2001, s. 538. 
Rzeszowscy Żydzi okazywali lojalność niepodległemu państwu. Obchodzili polskie święta narodowe. Jednocześnie dochodziło do konfliktów między polską większością a Żydami. Bezpośrednio po zakończeniu wojny władzę w kahale sprawowali członkowie ruchu syjonistycznego, począwszy od pierwszej połowy lat dwudziestych tzw. ortodoksi, a później stronnictwo nazywane „partią kahalna”. W społeczności żydowskiej miasta dużą rolę odgrywali chasydzi. Największymi wpływami politycznymi cieszyli się syjoniści, „ortodoksi" i organizacje chasydzkie. Znacznie mniejsze poparcie miał socjalistyczny Bund.

Zdecydowana większość społeczności rzeszowskiej prowadziła życie zgodne $z$ tradycyjnymi zasadami swojej religii. Istniało dużo starozakonnych szkół religijnych. Zasad religii mojżeszowej nauczano też w publicznych i prywatnych żydowskich szkołach świeckich. Na terenie międzywojennego Rzeszowa działało Żydowskie Stowarzyszenie Szkoły Ludowej, Średniej i Zawodowej, prowadzące szkołę powszechna, gimnazjum i liceum $z$ hebrajskim językiem nauczania. Oprócz tego aktywnością wykazywały się także inne stowarzyszenia i organizacje: religijne, charytatywne, zawodowe, kulturalno-oświatowe. Nie brakowało żydowskich klubów sportowych.

Krótko przed wybuchem II wojny światowej, w 1938 r., w Rzeszowie mieszkało ponad 13 tysięcy osób narodowości żydowskiej (około 30\% liczby mieszkańców miasta) ${ }^{3}$. Żydzi stanowili większość rzeszowskich handlowców. Na początku lat trzydziestych należało do nich $72 \%$ miejscowych firm handlowych. Często pracowali także w sferze usług, np. w 1937 r. więcej niż połowa osób wchodząca w skład miejscowych cechów: krawieckiego, fryzjerskiego i Cechu Zjednoczonych Rzemieślników była Żydami. Poza tym Rzeszów należał do największych skupisk inteligencji żydowskiej w województwie lwowskim, obok Lwowa, Drohobycza i Przemyśla ${ }^{4}$. Badacz dziejów ludności żydowskiej Wacław Wierzbieniec podkreśla, że Lwów oraz wymienione trzy ośrodki miejskie, „będące dużymi skupiskami ludności żydowskiej, odgrywały największą rolę kulturotwórczą" wśród Żydów $z$ terenu województwa lwowskiego ${ }^{5}$.

${ }^{3}$ W. Wierzbieniec, Żydzi rzeszowscy, [w:] Encyklopedia Rzeszowa, red. J. Draus, Rzeszów 2004, s. 823-825; idem, Żydzi rzeszowscy, [w:] Encyklopedia Rzeszowa, red. J. Draus, G. Zamoyski, Rzeszów 2011, s. 1021-1022; i d e m, Żydzi w województwie lwowskim..., s. 22; i d e m, Stosunki wyznaniowe, [w:] Dzieje Rzeszowa.., s. 447, 463-464; M.E. Ożóg, op. cit., s. 517; A. Potocki, op. cit., s. 159-160.

${ }^{4}$ W. Wierzbieniec, Żydzi w województwie lwowskim..., s. 185, 248.

${ }^{5}$ Ibidem, s. 358. 
Miejscowi Żydzi w dużym stopniu ulegali polonizacji. Świadczy o tym to, że w 1921 r. jedynie 62\% osób wyznania mojżeszowego deklarowało narodowość żydowska, natomiast reszta uważała się za Polaków. Po 10 latach zaledwie 58,5\% ludzi wyznajacych powyższą religię posługiwało się językiem żydowskim (jidysz). Mała część utożsamiała się $z$ mowa hebrajska, mimo propagandy prowadzonej przez syjonistów ${ }^{6}$. Dlatego istniało zapotrzebowanie na pisma żydowskie w języku polskim, mające pomóc asymilującej się ludności w ponownym utożsamieniu się $z$ pierwotna narodowością.

Dwa żydowskie „Przeglądy Rzeszowskie” nie były pierwszymi periodykami o tym tytule. W latach 1883-1886 w Rzeszowie ukazywał się polski dwutygodnik „Przegląd Rzeszowski”, poświęcony zagadnieniom społecznym, gospodarczym i literaturze. W 1883 r. w roli nakładcy, redaktora odpowiedzialnego i drukarza występował Jan Andrzej Pelar. Od połowy 1883 r. redaktorem odpowiedzialnym był Ferdynand Nowak ${ }^{7}$.

"Przegląd Rzeszowski” z 1927 r. wychodził raz na dwa tygodnie, podobnie jak pismo $z$ okresu 1883-1886. Ukazywał się od 28 maja do 24 grudnia w soboty. Wydano 16 numerów. Zadania wydawcy i redaktora wykonywał C.L. Platzer (nr 1-12), a po nim M.M. Fröchlich (nr 13 i następne). Czasopismo nosiło podtytuł „Bezpartyjny dwutygodnik żydowski"s. Podkreślanie bezpartyjności miało służyć zjednaniu tytułowi czytelników ponad podziałami politycznymi, było deklaracją obiektywizmu w kwestiach ideologicznych.

Redakcja zajmowała się problemami ekonomicznymi i socjalnymi dotyczącymi Żydów. Przypominała o zbliżających się wyborach parlamentarnych. Przekazywała informacje na temat miejscowego żydowskiego życia kulturalnego i sportu. Dużo miejsca przeznaczano na omawianie aktualnych problemów rzeszowskiego samorządu miejskiego. Teksty nie były podpisywane przez autorów ${ }^{9}$.

${ }^{6}$ W. Bonusiak, Stosunki ludnościowe, [w:] Dzieje Rzeszowa..., s. 94-95.

7 S. Darłakow a, Prasa Rzeszowa XIX i XX wieku, Rzeszów 1966, s. 23.

8 Ibidem, s. 42-43; eadem, Czasopiśmiennictwo i prasa, [w:] Dzieje Rzeszowa..., s. 238; A. Jagusztyn, Dzieje drukarstwa i ksiegarstwa $w$ Rzeszowie w latach 1840-1939, Rzeszów 1974, s. 94. Por. „Przegląd Rzeszowski” [dalej: PR], 1927, nr 1 (nr datowany - Rzeszów, sobota, 28 V 1927), 9-15, 16 (ostatni numer, datowany - Rzeszów, sobota, 24 XII 1927), nr 1, 9-11, s. 4 (informacja w stopce redakcyjnej - o wydawcy i redaktorze odpowiedzialnym), 13-15, s. 4 (informacja w stopce redakcyjnej - o wydawcy i redaktorze odpowiedzialnym).

${ }^{9}$ S. Darłakow a, Prasa Rzeszowa...., s. 43. 
Wszystkie numery dwutygodnika z 1927 r. miały format 44 x 32 cm. Liczyły po cztery strony. Cena numeru wynosiła $20 \mathrm{gr}^{10}$. Pismo drukowano w nakładzie 600 egzemplarzy ${ }^{11}$. Redakcja i administracja znajdowały się w Rzeszowie na ul. 3 Maja 912. Czasopismo miało konto $\mathrm{w} \mathrm{PKO}^{13}$. W numerze, datowanym na 24 grudnia, zapowiadano zwiększenie częstotliwości ukazywania się „Przeglądu Rzeszowskiego”, który od 5 stycznia 1928 miał się stać tygodnikiem ${ }^{14}$. Tak się jednak nie stało, a numer, w którym to obiecywano, okazał się ostatni.

Numer pierwszy z 28 maja otwarto artykułem wstępnym Od Redakcji, umieszczonym na pierwszej stronie bezpośrednio pod winieta $^{15}$, napisanym najprawdopodobniej przez C.L. Platzera, który podpisał się w stopce redakcyjnej u dołu ostatniej strony jako: "Redaktor odpowiedzialny C.L. Platzer"16. Redakcja przypomniała o trudnej międzynarodowej oraz krajowej sytuacji politycznej i gospodarczej. Określiła tożsamość narodowa swoja i odbiorców, używając zwrotu „my, Żydzi”. Zapowiedziała, że skupi się głównie na zadaniach informacyjnych, przekazujacc czytelnikom bieżące wiadomości o życiu politycznym, gospodarczym i kulturalnym Rzeszowa. Podkreśliła swą bezpartyjność, tożsama z apolitycznością. Obiecywała, że będzie realizować następującą misję: „Niech organ nasz informuje rząd, władze i [...] gros naszego społeczeństwa o potrzebach wszystkich jego warstw bez względu na przynależność partyjna dla dobra ogółu i państwa"17. Rzeszowian zachęcała do prenumeraty, publikujacc hasło reklamowe: „Abonujcie Przegląd Rzeszowski"18.

Do kluczowych tematów, obecnych na łamach periodyku, należały wybory do rady miejskiej w Rzeszowie, a później działalność tego organu. W pierwszym numerze podkreślano konieczność stworzenia ponadpartyjnego żydowskiego sojuszu w wyborach samorządowych, „jednolitego frontu żydowskiego w wyborach do rady

10 Ibidem. Por. PR, 1927, nr 1, 9-15.

11 S. Darłakowa, Prasa Rzeszowa...., s. 43; eadem, Czasopiśmiennictwo i prasa..., s. 238.

12 Por. PR, 1927, nr 1, 9-16 (winieta na s. 1 każdego numeru).

${ }^{13}$ Por. PR, 1927, nr 9-16 (winieta na s. 1 każdego numeru).

${ }^{14}$ Od Redakcji, PR, 1927, nr 16, s. 3.

15 Od Redakcji, PR, 1927, nr 1, s. 1.

16 PR, 1927, nr 1, s. 4 (stopka redakcyjna u dołu strony).

17 Od Redakcji..., PR, 1927, s. 1.

18 PR, 1927, nr 1, s. 2. 
miejskiej". Dostrzegano słabości we wszystkich ugrupowaniach mogacych się liczyć w rywalizacji wyborczej: stowarzyszeniach handlowców, związku rzemieślników i rękodzielników Jad Charucim, $\mathrm{u}$ syjonistów, w stronnictwie Mizrachi oraz w środowiskach ortodoksyjnych. Omawiane kręgi polityczne oceniano jako wewnętrznie rozbite $^{19}$. Konieczność jedności rzeszowskich Żydów w wyborach zaznaczano też $\mathrm{w}$ innej przedwyborczej publikacji, ostrzegając, że „chorobliwa ambicja jednostek może doprowadzić do uszczuplenia naszego minimalnego stanu posiadania [...]"20.

Po wyborach systematycznie publikowano sprawozdania $z$ posiedzeń rady miasta, kładąc nacisk na działania członków Klubu Radnych Żydowskich, skupiającego deputatów Żydów, niezależnie od dzielących ich orientacji politycznych. Sprawozdania stanowią ważne źródło informacji dla osób zainteresowanych dziejami mniejszości żydowskiej, a także innymi zagadnieniami $z$ historii miasta ${ }^{21}$. Radni żydowscy występowali w obronie interesów swych rodaków - ubogich kupców ${ }^{22}$. Po rozpoczęciu prac przez radę ogłoszono deklarację klubu ${ }^{23}$. Później krytykowano samorządowców, wśród nich Żydów, za niedotrzymywanie obietnic wyborczych. W numerze 13 z 12 listopada stwierdzono: „Przyrzeczenia przedwyborcze naszych wybranych zaczynaja trochę przedwcześnie chromać"24. Charakter satyryczny miał artykuł Mikołaj Rej na posiedzeniu rady miejskiej, będacy parodia sprawozdania $z$ obrad, napisany językiem $z$ pozoru staropolskim. Osiagnnięciu takiego efektu miało służyć nadużywanie zdrobnień. Rzeszów został nazwany "miasteczkiem choruteńkim”, a lokalny polityk „Cezarkiem” i „burgmeisterkiem”25. Do jednej z ważniejszych uchwał rady odnosiła się wypowiedź publicystyczna, zamieszczona na pierwszej stronie ostatniego numeru. Autor krytykował władze miasta za obciążanie mieszkańców dodatkowymi kosztami komunalnymi: „Kupiectwo i rzemiosło żydowskie zbyt

19 Apetyty i szanse, PR, 1927, nr 1, s. 1-2.

${ }^{20}$ Rzeszowski Bałkan przedwyborczy, PR, 1927, nr 1, s. 2.

${ }^{21}$ Por. $Z$ inauguracyjnego posiedzenia rady miejskiej, PR, 1927, nr 1, s. 1; $Z$ posiedzenia rady miejskiej, PR, 1927, nr 10, s. 3; $Z$ posiedzenia rady miejskiej, PR, 1927, nr 11, s. 3; Z posiedzenia rady miejskiej, PR, 1927, nr 13, s. 1; Z obrad rady miejskiej, PR, 1927, nr 16, s. 3.

${ }_{22} Z$ posiedzenia rady miejskiej, PR, 1927, nr 11, s. 3.

${ }^{23}$ Deklaracja Klubu Radnych Żydowskich, PR, 1927, nr 9, s. 1 (deklaracja datowana: Rzeszów, dnia 8 IX 1927).

${ }^{24}$ Pierwsze rozczarowania..., PR, 1927, nr 13, s. 3.

${ }^{25}$ Por. Mikołaj Rej na posiedzeniu rady miejskiej, PR, 1927, nr 14, s. 1. 
już jest obarczone podatkami, ażeby mogło jeszcze dalsze ciężary udźwignać. Walka o byt i chleb codzienny jeszcze nigdy tak ciężką nie była na ulicy żydowskiej. Każdy bezwzględnie kupiec żydowski już dzisiaj pada pod ciężarem podatków, a konkurencja nie pozwala na uzyskanie dochodów, które by umożliwiły byt spokojny"26.

$\mathrm{Na}$ łamach dwutygodnika polemizowano $z$ endecka „Ziemia Rzeszowska”, której publicyści atakowali miejscowych Żydów i ich organ prasowy ${ }^{27}$. Zwracano uwage na przypadki zachowań antyżydowskich. Pisano o złej sytuacji młodzieży żydowskiej, kształcącej się w szkołach, podkreślając: „Jest to tajemnica poliszynela, iż antysemityzm w naszych gimnazjach panoszy się w okropny sposób i że uczniowie żydowscy przechodza prawdziwe katusze moralne"28. Praw obywatelskich mieszkańców regionu broniono także, piętnując niektórych urzędników za stosowanie represji wobec obywateli ${ }^{29}$.

Często zajmowano się sprawami związanymi $z$ funkcjonowaniem kahału, czyli gminy żydowskiej. Stosunki panujące we władzach rzeszowskiego kahału oceniano negatywnie, zarzucając stojacym na jego czele osobom prywate i tworzenie „rządów klik”, używając określeń „bagno kahalne"30 i „cuchnące bagienko"31. Obrady rady kahału nazywano "stałym teatrem w Pipidówce”, nawiązując do tytułu powieści Michała Bałuckiego Pan burmistrz z Pipidówki. W numerze 15 relacjonowano satyrycznie posiedzenie rady, stosując formę recenzji ze spektaklu teatralnego ${ }^{32}$. Na przykładzie konfliktu, związanego ze stroną finansową działalności jednej z bożnic, przekonywano o konieczności jawności wydatkowania środków ofiarowywanych przez ludność na cele religijne ${ }^{33}$. Popularyzowano

${ }^{26}$ Na marginesie uchwały rady miejskiej o zaciagnięcie pożyczki na budowę wodociagów, kanalizacji, rzeźni i targowicy, PR, 1927, nr 16, s. 1.

${ }^{27}$ Por. Przyjmujemy wyzwanie..., PR, 1927, nr 10, s. 2; Bieg na przełaj przez horyzont duchowy „Ziemi Rzeszowskiej”, PR, 1927, nr 13, s. 2; Maszynka kawowa..., PR, 1927, nr 15, s. 2.

${ }_{28}$ Opiekun młodzieży żydowskiej, PR, 1927, nr 14, s. 2.

29 Por. Pan Naczelnik stacji szykanuje pasażerów, PR, 1927, nr 11, s. 3 (w notatce chodziło o szykany zastosowane przez naczelnika stacji kolejowej w Rzeszowie wobec mieszkanki Jarosławia Idy Dobrzyc. Oprócz tego naczelnik użył obraźliwego epitetu „kacapy”).

${ }^{30}$ Por. Z bagna kahalnego, PR, 1927, nr 9, s. 2; Pana Schlagera kontrolować nie wolno, PR, 1927, nr 10, s. 2; Z bagienek „samorzadowych”, PR, 1927, nr 14, s. 2.

31 Wszyscy rzadza!!, PR, 1927, nr 11, s. 2.

${ }^{32}$ Stały teatr $w$ Pipidówce..., PR, 1927, nr 15, s. 1-2.

${ }_{33}$ Pana Schlagera kontrolować nie wolno..., s. 2. 
wybory uzupełniające do rady gminy żydowskiej ${ }^{34}$ i wydrukowano sprawozdanie $z$ jej obrad ${ }^{35}$. Popierano działania w kierunku zdemokratyzowania gmin żydowskich ${ }^{36}$. Krytykowano samorzad miejski jako nieudolny, tak samo jak kahalny ${ }^{37}$.

Za istotną inicjatywę uznawano budowę "domu żydowskiego" w Rzeszowie, mającego być ośrodkiem miejscowego żydowskiego życia społecznego i kulturalnego, wyposażonym w salę teatralną. $Z$ przejęciem omawiano problemy towarzyszace budowie obiektu ${ }^{38}$.

W związku ze zbliżajacymi się wyborami parlamentarnymi przekonywano czytelników do idei solidarnej walki, wolnej od różnic partyjnych, o reprezentację ludności żydowskiej w sejmie. Wypowiadano nadzieję, że „Dzisiejsi wyborcy żydowscy nie są więcej tym motłochem wyborczym, który się kiedyś na sznurku prowadziło, nie, to dzisiaj uświadomiona masa, która nie będzie inaczej glosowała, aniżeli jej dyktuje poczucie honoru osobistego i narodowego. A ten skieruje sie przeciwwszystkim, którzy spróbujązłamaćjednolity front"39. Popierano zawieranie sojuszy politycznych z innymi mniejszościami narodowymi, natomiast sprzeciwiano się analogicznym układom ze stronnictwami polskimi ${ }^{40}$. Wyśmiewano się $z$ populizmu kandydatów składających wyborcom obietnice ekonomiczne niemożliwe do realizacji ${ }^{41}$. W dniu 12 listopada zarzucano dotychczasowym posłom brak dokonań i stwierdzano $z$ satysfakcją: „Posłowie sejmowi pakuja już manatki...”, „Sejm endecko-chieńsko-piastowski skończył wreszcie swój żywot" ${ }^{2}$. Krytykowano część partii żydowskich uczestniczących w walce o mandaty ${ }^{43}$.

${ }^{34}$ Syjoniści, ortodoksja i kahat, PR, 1927, nr 10, s. 1; Czy możliwy jest sojusz syjonistów $z$ ortodoksja przy wyborach do kahału (głos syjonisty), PR, 1927, nr 10, s. 1-2; Czy możliwy jest sojusz syjonistów z ortodoksja przy wyborach do kahału (głos mizrachisty), PR, 1927, nr 14, s. 2.

${ }^{35}$ Por. Z posiedzenia kahału, PR, 1927, nr 12, s. 1-2.

${ }^{36}$ Demokratyzacja gmin żydowskich, PR, 1927, nr 12, s. 2.

${ }_{37} Z$ bagienek „samorzadowych”..., s. 2.

${ }^{38}$ W poszukiwaniu mistrzów do budowy domu żydowskiego, PR, 1927, nr 9, s. 2; Drugi kierownik budowy domu żydowskiego, PR, 1927, nr 10, s. 2; Drugi kierownik budowy domu żydowskiego (c.d.), PR, 1927, nr 11, s. 2; Drugi kierownik budowy domu żydowskiego (c.d.), PR, 1927, nr 12, s. 2.

$39 \dot{Z} y d z i$ wobec zbliżajacych się wyborów sejmowych, PR, 1927, nr 12, s. 1.

40 Ibidem.

${ }^{41}$ Por. Mój program, PR, 1927, nr 16, s. 2. Autor uczynił narratorem przywołanego satyrycznego artykułu kandydata na posła, obiecującego wyborcom zniesienie wszelkich podatków, ibidem.

42 Podzwonne, PR, 1927, nr 13, s. 1.

${ }^{43}$ Por. Zasadniczy grzech „Agudy” (na tle kampanii wyborczej), PR, 1927, nr 14, s. 1; Z chaosu przedwyborczego, PR, 1927, nr 15, s. 1; Niefortunny sojusz, PR, 1927, nr 16, s. 2. 
Popierano działalność rządu mającego na czele marszałka Józefa Piłsudskiego ${ }^{44}$. W ten sposób pośrednio wyrażano aprobatę dla hasła sanacji państwa.

Komentowano krajową politykę gospodarcza, licząc na poprawę sytuacji ekonomicznej. Apelowano do władz państwowych, by zlikwidowały biurokrację, co miało zaowocować obniżeniem podatków ciążących na społeczeństwie, a także by zorganizowały tanie kredyty ${ }^{45}$. Objaśniano czytelnikom przepisy w zakresie działalności handlowej ${ }^{46}$.

Rzadko zajmowano się wydarzeniami zagranicznymi. Informując o konferencji międzynarodowej odbywającej się w Genewie, stwierdzono konieczność współpracy gospodarczej między państwami, koniecznej dla „rozwoju ekonomicznego świata" ${ }^{4}$. W dniu 12 listopada 1927 r. odniesiono się do wyroku francuskiego sądu, który uniewinnił Samuela Schwarzbarta, będącego zabójca ukraińskiego przywódcy Semena Petlury. Przypomniano o odpowiedzialności Petlury za pogromy ludności żydowskiej. Jednocześnie przekonywano, że $z$ petlurowcami i ich wodzem nie można utożsamiać całego narodu ukraińskiego ${ }^{48}$.

Starano się kształtować, względnie wzmacniać, wrażliwość społeczną u czytelników, pisząc o żydowskiej działalności socjalnej na rzecz dzieci objętych opieka przez ochronkę, osób starszych, sierot. Konstatowano, że instytucjom zajmującym się opieka społeczną brakuje zrozumienia ze strony miejscowej społeczności, poza tym w większości są one źle zarządzane ${ }^{49}$. Popierano akcję zbiórki pieniędzy na potrzeby domu sierot w Rzeszowie ${ }^{50}$. W niewielkiej notatce

${ }_{44}$ Połów serc, PR, 1927, nr 16, s. 1; Zmierzch..., PR, 1927, nr 12, s. 2 (humoreska polityczna, w której część Żydów, niepopierająca polityki Piłsudskiego, zastanawia się nad ewentualnym sojuszem wyborczym $z$ endekami).

${ }^{45}$ Nasze życzenie (na marginesie nowej pożyczki), PR, 1927, nr 11, s. 1.

46 Nowe przepisy o wpisie do rejestru handlowego, PR, 1927, nr 11, s. 2.

47 Draf, Przed nowa era, PR, 1927, nr 1, s. 2-3.

48 Po procesie Schwarzbarta, PR, 1927, nr 13, s. 2.

49 Dookoła instytucji żydowskich, PR, 1927, nr 1, s. 2. Por. O byt najnieszczęśliwszych, PR,1927, nr 13, s. 1-2 (apel o zainteresowanie społeczne losem sierot i bezdomnych dzieci); O byt najnieszczęśliwszych, PR, 1927, nr 14, s. 3 (nawiazanie do wcześniejszej publikacji pod tym samym tytułem - publikacja listu od mecenasa dr. Wilhelma Hochfelda).

${ }^{50}$ Por. O byt najnieszczęśliwszych, PR, 1927, nr 14, s. 3; Lista nr 1 Funduszu Łańcuchowego dla zakładu sierot żydowskich $w$ Rzeszowie, PR, 1927, nr 14, s. 3; Fundusz łańcuchowy na rzecz zakładu sierot żydowskich $w$ Rzeszowie. Lista nr 2, PR, 1927, nr 15, s. 3; Fundusz łańcuchowy na rzecz zakładu sierot żydowskich 
zachęcano do udziału w dziecięcym balu - maskaradzie, przygotowanym przez miejscową ochronkę żydowską w Szpitalu Żydowskim na niedzielę 18 grudnia. Imprezie miał towarzyszyć „dancing dla dorosłych" 51 .

Naturalne w piśmie lokalnym było apelowanie do władz miejskich o poprawę higieny i estetyki Rzeszowa. Redakcja nawoływała magistrat do starań $O$ czystość miasta, pisząc o brudzie widocznym na ulicach i placach. Przekonywała, że żądania w stosunku do właścicieli posesji, by dbali o porządek, nie będa skuteczne, jeśli władze samorządowe nie dadza przykładu, np. organizując systematyczne mycie bruków wodą $z$ beczkowozu ${ }^{52}$. Po pierwszym posiedzeniu nowej rady Rzeszowa wydrukowano humoreskę proza, zatytułowana Sen..., w której anonimowy publicysta opisał swój fikcyjny spacer po Rzeszowie czystym, pełnym odnowionych budynków i zieleni, charakteryzujacym sie jezdniami w dobrym stanie, a wieczorem i w nocy mocno oświetlanym latarniami elektrycznymi, a nie lampami gazowymi. $\mathrm{Na}$ miejscu ruder widział efektowne miejskie inwestycje, takie jak wodotrysk przed dworcem kolejowym, „otoczony duża rotundą zieleni”"53. Relacjonował też, że „Ogród miejski zmienił się do niepoznania. Krowy pana Piątka pasły się gdzie indziej, nie było już komarów, cuchnacy stawek gdzieś wyparował, a klomby i zieleń była tak obfita, że aż chciało się zaglądnać w te zarośla, czy tam nie ma - Ewy z Adamem" ${ }^{4}$. Rynek z pomnikiem Tadeusza Kościuszki miał wyglądać tak: „W środku rynku głównego stała elektryczna lampa łukowa wysoka na 3 piętra o sile 1000 świec, a na dolnej części tego słupa znajdowała się przymocowana artystycznie wykonana tablica pamiątkowa $z$ napisem "Ku czci tej Rady miejskiej - która umyła zwycięzcę spod Racławic". O zły stan higieny Rzeszowa i jego brzydki wygląd oskarżano rzązaca radę miasta ${ }^{55}$. W innym artykule wymieniano nazwy ulic o chodnikach i brukach wymagajacych naprawy: Słowackiego, Przesmyk, Baldachówka, Joselowicza, Kopernika, Lwowska, Batorego, szlak $z$ Nowego Miasta do Lwowskiej. Naprawy wymagał nawet chodnik na Rynku, znajdujący się w bezpośrednim sąsiedztwie ratusza ${ }^{56}$.

w Rzeszowie. Lista nr 3, PR, 1927, nr 16, s. 3. Redakcja „Przegladu Rzeszowskiego” przekazała na „fundusz łańcuchowy” $20 \mathrm{zl}$, Lista $n r$ 1..., s. 3.

${ }^{51}$ Nadesłane, PR, 1927, nr 15, s. 3.

52 O czystość miasta, PR, 1927, nr 9, s. 2.

53 Sen..., PR, 1927, nr 11, s. 1-2.

54 Ibidem, s. 1.

55 Ibidem, s. 2.

${ }^{56}$ Z kalejdoskopu miejskiego, PR, 1927, nr 15, s. 2. 
O sprawach lokalnych informowano także w regularnie publikowanej rubryce Kronika, prowadzonej zgodnie $z$ zapowiedzia $z$ pierwszego numeru: „Począwszy od następnego numeru będzie Przegląd Rzeszowski zamieszczał bardzo obszerną kronikę miejscowa" ${ }^{27}$. W dziale tym przekazywano najważniejsze ogólnopolskie wiadomości polityczne i ekonomiczne. Dużo pisano o miejskich sprawach kryminalnych i wypadkach, a także patologiach społecznych, ostrzegając przed przestępczością i prostytucją ${ }^{58}$. Interesowano się wydarzeniami $z$ życia kahału ${ }^{59}$. Informowano o zebraniach żydowskich organizacji zawodowych i politycznych oraz innych faktach $z$ miejscowego życia politycznego. Zachęcano do udziału w imprezach kulturalnych ${ }^{60}$.

Niekonsekwentnie prowadzono kronikę sąową ${ }^{61}$. Równie rzadko ukazywały się korespondencje $z$ terenu. W grudniu ogłoszono tekst na temat wyborów samorzadowych w podrzeszowskim Tyczynie oraz procesu sądowego między tamtejszymi burmistrzem i wiceburmistrzem o obrazę ${ }^{62}$.

Częściej drukowano publikacje satyryczne. Oprócz przywołanych publikacji proza były to czasem utwory wierszowane. W wierszu Cofamy... (Melodie może każdy „dorobič) przypominano o idei wolności słowa, ważnej dla redakcji czasopism ${ }^{63}$. Przed wyborami do parlamentu przedstawiono humorystyczny obraz żydowskiego życia politycznego w $\mathrm{RP}^{64}$.

Redakcja upowszechniała sztukę teatralną. W pierwszym numerze zamieściła artykuł Współcześni a teatr, w którym poddano krytyce istniejacce zespoły amatorskie. Za słabość teatru amatorskiego uznano brak zdolnych reżyserów oraz to, że aktorzy amatorzy nie pracuja nad swym rozwojem artystycznym. Uważano, że sytuacja może się zmienić, jeśli będa organizowane kursy i odczyty o tematyce teatralnej ${ }^{65}$. W następnych numerach publikowano recenzje

57 Od Redakcji, PR, 1927, nr 1, s. 3.

58 Kronika, PR, 1927, nr 9, s. 3; Kronika, PR, 1927, nr 12, s. 2-3; Kronika, PR, 1927, nr 12, s. 3; Kronika, PR, 1927, nr 14, s. 3; Kronika, PR, 1927, nr 15, s. 3.

59 Kronika, PR, 1927, nr 10, s. 3.

60 Por. m.in. Kronika, PR, 1927, nr 12, s. 3; Kronika, PR, 1927, nr 15, s. 3.

${ }^{61}$ Por. $Z$ sali sadowej, PR, 1927, nr 14, s. 3.

$62 Z$ powiatu, PR, 1927, nr 15, s. 3.

63 Cofamy... (Melodie może każdy „dorobič), PR, 1927, nr 9, s. 3.

64 ?, PR, 1927, nr 12, s. 3 (wiersz satyryczny z nagłówkiem Zygzaki).

65 Współcześni a teatr, PR, 1927, nr 1, s. 1. 
z żydowskich przedstawień amatorskich, dawanych w Rzeszowie, a także notatki na temat miejscowego życia teatralnego ${ }^{66}$.

Znacznie mniej publikacji miało na celu popularyzację czytelnictwa książek ${ }^{67}$, co źle świadczy o redakcji czasopisma.

Częściej pisano o sporcie. Reklamowano imprezy sportowe i ogłaszano wyniki rozgrywek. Na niedzielę 29 maja zapowiadano mecz piłki nożnej między rzeszowską drużyna z klubu Bar Kochba, a 3. Pułkiem Legionów $z$ Jarosławia. Impreza miała się odbyć na boisku Bar Kochby ${ }^{68}$. Czasem publikowano Kronike sportowa, zawierająca informacje o lokalnych i regionalnych wydarzeniach $z$ dziedziny futbolu, odbywających się $z$ udziałem sportowców żydowskich. Pisano m.in. o Bar Kochbie $z$ Rzeszowa i drużynie Samson $z$ Tarnowa ${ }^{69}$.

Numery archiwalne „Przeglądu Rzeszowskiego” sa dokumentem codziennego życia miasta dzięki nekrologom, kondolencjom, ogłoszeniom i reklamom. Nekrologi oraz kondolencje trafiały do rubryki Kronika żałobna ${ }^{70}$. W piśmie zamieszczano też podziękowania bliskich zmarłych osób za kondolencje czy za udział w pogrzebie ${ }^{71}$.

Chcąc pozyskać czytelników i popularyzatorów, zapowiadano bezpłatne publikowanie ogłoszeń stowarzyszeń żydowskich z Rzeszowa $^{72}$. Ogłoszenia zamieszczane w periodyku dotyczyły wydarzeń

${ }^{66}$ Por. m.in. Z teatru. „Jastrzą", PR, 1927, nr 1, s. 3 (recenzja inscenizacji sztuki Jastrzab, napisanej przez Francisa de Croisseta, zaprezentowanej $21 \mathrm{~V}$ 1927 r. w sali Szpitala Żydowskiego przez Żydowskie Towarzystwo Muzyczno-Dramatyczne); $Z$ teatru, PR, 1927, nr 11, s. 3 (recenzja spektaklu tragedii Leonida Andrejewa Siedmiu powieszonych, zagranego w Rzeszowie 1 X 1927 r. przez miejscowe siły amatorskie); $Z$ teatru, PR, 1927, nr 15, s. 3 (recenzja przedstawienia sztuki Paula Lindaua Prokurator dr Hallers, które odbyło się 27 XI 1927 r. w sali Polonia. Wystąpił zespół teatralny Scena, pokazując widzom wersję tekstu Lindaua, opracowaną dla teatrów żydowskich przez Jonasa Turkowa); $Z$ teatru, PR, 1927, nr 16, s. 3 (recenzja realizacji sztuki Berkowicza Moszke Chazer, danej przez Scenę 17 XII 1927 r. w sali Szpitala Żydowskiego).

${ }^{67}$ Por. Obraz ducha żydowskiego (ze świata ksiażek), PR, 1927, nr 13, s. 3 (recenzja pierwszego tomu leksykonu Salmena Reisena o literaturze żydowskiej, ogłoszona na krótko przed wydaniem w warszawskiej firmie Bycher tomu drugiego).

68 PR, 1927, nr 1, s. 3 (niezatytułowane reklamy i zapowiedzi, umieszczone poza rubryka Kronika sportowa).

${ }^{69}$ Por. Kronika sportowa, PR, 1927, nr 1, s. 3; Kronika sportowa, PR, 1927, nr 9, s. 3.

${ }^{70}$ Por. Kronika żałobna, PR, 1927, nr 1, s. 3. Por. też kondolencje dla Samuela Rosnera $z$ powodu śmierci ojca, przekazane za pośrednictwem dwutygodnika przez towarzyszy ze stowarzyszenia Haszachar, ogłoszone poza Kronika żałobna, PR, 1927, nr 13, s. 3.

${ }^{71}$ Por. Podziękowanie, PR, 1927, nr 12, s. 3.

${ }^{72}$ Od Redakcji, PR, 1927, nr 1, s. 3. 
kulturalnych i innych. Czasem były to podziękowania, np. dla firmy ochroniarskiej Zakład Czuwania i Ochrony w Rzeszowie, występującej też pod nazwą Zakład Straży Nocnej Czuwaj, albo wyrazy wdzięczności od stowarzyszeń dla współpracowników za wspieranie działalności, względnie od instytucji prowadzących działalność charytatywną. Zdarzały się wiadomości o zmianie adresów firm ${ }^{73}$, ogłaszane też między reklamami ${ }^{74}$.

Cała ostatnia stronę wszystkich czterostronicowych numerów przeznaczano na reklamy. Czasem trafiały one także na inne strony. Współcześnie stanowią dokument działalności produkcyjnej, handlowej, usługowej, bankowej, a także medycznej, prawniczej oraz prywatnej edukacyjnej, głównie żydowskiej, prowadzonej w mieście pod konkretnymi adresami ${ }^{75}$. W pierwszym numerze zwracano sie do potencjalnych reklamodawców: „Uwaga!! Pismo nasze nawiązało stosunki $z$ cała prowincja i rozejdzie się po wszystkich pobliskich miejscowościach, jak Łańcut, Tyczyn, Strzyżów, Sokołów, Kolbuszowa itp., inserujcie zatem w "Przeglądzie Rzeszowskim", gdyż reklama jest dźwignia handlu!!!”76.

W 1932 r. czasopismo o tym samym tytule istniało od 18 marca do 24 czerwca. Opublikowano jedynie 15 numerów. Tym razem był to tygodnik. Redakcja podobnie jak redaktorzy „Przeglądu Rzeszowskiego" z 1927 r. deklarowała apolityczność, używając podtytułu „Bezpartyjny tygodnik żydowski”. Redaktorem odpowiedzialnym i wydawca był Samuel Lubasz. Numery podobnie jak w poprzednim przypadku miały po cztery strony o rozmiarach 44 x $32 \mathrm{~cm}$. Nie zmieniła się również cena numeru, wynosząca podobnie jak pięć lat wcześniej 20 gr $^{77}$. Siedziba redakcji mieściła się w Rzeszowie na Rynku 24 i wkrótce pod adresem Rynek 23. Redaktor był dostępny dla interesantów od ok. godziny 13.00, 14.00, a później od ok. 13.00, 15.0078.

${ }^{73}$ Por. m.in. Komunikaty, PR, 1927, nr 1, s. 3; Podziękowanie, PR, 1927, nr 9, s. 3; Nadesłane, PR, 1927, nr 10, s. 3; Nadesłane, PR, 1927, nr 11, s. 3; Nadesłane, PR, 1927, nr 12, s. 3; Nadesłane, PR, 1927, nr 13, s. 3; Nadesłane, PR, 1927, nr 15, s. 3; Nadestane, PR, 1927, nr 16, s. 3.

${ }_{74}$ Por. np. PR, 1927, nr 1, s. 4.

75 Por. PR, 1927, nr 1, s. 4; nr 9, s. 3-4; nr 10, s. 3-4; nr 11, s. 4; nr 12, s. 3-4; nr 13 , s. $3-4$; nr 14, s. 1 , 4; nr 15, s. 3-4; nr 16, s. 4.

${ }^{76}$ PR, 1927, nr 1, s. 3.

77 S. D arłakow a, Prasa Rzeszowa..., s. 44; e a d e m, Czasopiśmiennictwo i prasa..., s. 238; A. J a gu szty n, op. cit., s. 94-95. Por. PR, 1932, nr 1-12, 14-15 (nr 1 - datowany: Rzeszów, dnia 18 III 1932, nr 15, ostatni - Rzeszów, dnia 24 VI 1932).

${ }^{78} \mathrm{PR}, 1932$, nr 1-12, 14-15 (informacja o adresie redakcji i godzinach pracy redaktora - na s. 1 każdego numeru). 
„Przegląd Rzeszowski” z 1932 r. zawierał wiadomości i materiały publicystyczne o problemach społecznych i gospodarczych. Zamieszczano artykuły, a także notatki $z$ dziedziny lokalnej kultury i sportu. Publikowano kronikę miejscowa, żałobna, sportowa, korespondencje współpracowników z terenu. Popularyzowano literaturę piękną, publikując utwory epickie w podziale na odcinki ${ }^{79}$.

W numerze pierwszym z 18 marca znalazł się artykuł wstępny, którego autora należy utożsamiać z Samuelem Lubaszem, podpisanym na ostatniej stronie „Wydawca i redaktor odpowiedzialny: Sz. Lubasz w Rzeszowie"80. Autor zwrócił uwage na katastrofalna światowa i krajową sytuację gospodarczą oraz na to, że mniejszość żydowska odczuwa ja szczególnie wyraźnie, bo kryzys dotyka ją tak samo, jak pozostałych obywateli państwa, a jednocześnie skutkuje kierowaniem przeciw Żydom nastrojów antysemickich. Podobnie jak wcześniej C.L. Platzer, jednoznacznie zadeklarował poczucie tożsamości redakcji oraz czytelników, pisząc „My Żydzi”. Reklamował nowy tytuł jako kontynuację "Przeglądu Rzeszowskiego" z 1927 r., podajacc omyłkowo, że tamten periodyk wychodził „przed trzema laty". Zachęcał lokalna społeczność do kupowania i czytania tygodnika, a także do współpracy $z$ redakcja, przekonując: „Żydzi Rzeszowa! [...] skupcie się wszyscy dokoła Waszego organu! Popierajcie "Przegląd Rzeszowski», nie tylko pieniężnie przez prenumerowanie go, lecz głównie przez komunikowanie nam Waszej doli i niedoli, byśmy przed forum publiczne wytaczać mogli owe tak liczne lokalne bolączki, których w żadnym mieście nie brak. [...] Żydzi Rzeszowa! Współpracujcie z nami!"81. W numerze pierwszym i w części kolejnych kierowano do czytelników apel, drukowany prawie za każdym razem dużymi literami: „Rozpowszechniajcie Przegląd Rzeszowski"82.

Rzadziej niż w piśmie, do którego tradycji starano się nawiązywać, ogłaszano sprawozdania $z$ posiedzeń rady miasta. Nie zwracano uwagi tak systematycznie jak we wcześniejszym „Przeglądzie

79 S. Darłakowa, Prasa Rzeszowa..., s. 44-45; ea d e m, Czasopiśmiennictwo i prasa..., s. 238; PR, 1932, nr 1-12, 14-15.

${ }^{80}$ Od redakcji, PR, 1932, nr 1, s. 1. Por. PR, 1932, nr 1, s. 4 (stopka redakcyjna na dole strony). Samuel Lubasz z pewnościa jest autorem następującej publikacji: Jak się obraziłem ( $z$ udręczeń prowincjonalnego redaktora), PR, 1932, nr 8, s. 2-3.

${ }^{81}$ Od redakcji, PR, 1932, nr 1, s. 1.

${ }^{82} \mathrm{PR}, 1932$, nr 1, s. 2; nr 3, s. 1; nr 4, s. 2; nr 8, s. 3; nr 14, s. 3; nr 15 , s. 4. 
Rzeszowskim" na wystapienia radnych żydowskich ${ }^{83}$. Czasem ogłaszano inne wiadomości o rzeszowskim samorządzie lokalnym, szczególnie na temat obsady stanowisk ${ }^{84}$. Jako ważne traktowano wybory na funkcje samorządowe i w instytucjach komunalnych, czemu dano wyraz, publikując na pierwszej stronie numeru ósmego całostronicowy artykuł pt. Przed wyborem zastępcy burmistrza $i$ dyrektora Komunalnej Kasy Oszczędności ${ }^{85}$.

Starano się bronić praw obywatelskich mniejszości żydowskiej $\mathrm{i}$ innych mieszkańców miasta. W jednym $z$ numerów zamieszczono list do redakcji od czytelnika H.E., będacy informacja o łamaniu przez pocztę i policję tajemnicy korespondencji ${ }^{86}$. Zarzucano niechęć wobec Żydów burmistrzowi Rzeszowa Romanowi Krogulskiemu, piszacc, że „pana dra Krogulskiego [...] o zbytnią troskę o dobro

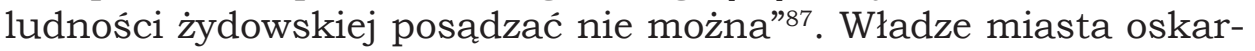
żano o dyskryminowanie mniejszości: „Ludność żydowska jest przez Magistrat specjalnie postponowana. Przy obsadzeniu różnych wakujących posad nie uwzględnia się w ogóle podań żydowskich petentów, a natomiast przyjmuje się urzędników, posiadających już emerytury i w dodatku też uboczne zajęcia. Stwarza się w ten sposób falangi uprzywilejowanych, podczas gdy inna grupa obywateli skazana jest na niedostatek i głód"88.

„Przegląd Rzeszowski” z 1932 r. był zwalczany przez „Ziemię Rzeszowska" analogicznie jak pismo Platzera i Fröchlicha. Redakcja „Ziemi Rzeszowskiej”, związana z Narodowa Demokracja, uprawiała publicystykę antyżydowska, na co „Przegląd Rzeszowski” odpowiadał polemikami ${ }^{89}$. W żydowskim piśmie napisano o prawicowym

${ }^{83} Z$ rady miejskiej, PR, 1932, nr 2, s. 3; $Z$ posiedzenia rady miejskiej $w$ dniu 30 maja. A więc mamy już zastępcę burmistrza, PR, 1932, nr 12, s. 1 ; $Z$ posiedzenia rady miejskiej $w$ dniu 16 czerwca b.r., PR, 1932, nr 15, s. 1.

${ }^{84}$ Por. Skład poszczególnych komisji Magistratu, PR, 1932, nr 2, s. 3; Skład poszczególnych komisji magistratu (ciag dalszy), PR, 1932, nr 3, s. 4; Zmiany personalne $w$ magistracie, PR, 1932, nr 15, s. 1.

85 Przed wyborem zastepcy burmistrza i dyrektora Komunalnej Kasy Oszczęności, PR, 1932, nr 8, s. 1. Por. Ta nauka w las nie pójdzie (artykuł dotyczacy sprawy „wyboru żydowskiego członka Zarządu Komunalnej Kasy Oszczędności”), PR, 1932, nr 10, s. 1-2; Po wyborze członka Zarzadu Komunalnej Kasy Oszczędności, PR, 1932, nr 11, s. 3.

${ }^{86}$ Pod adresem poczty, PR, 1932, nr 7, s. 4.

${ }_{87} Z$ posiedzenia rady miejskiej $w$ dniu 16 czerwca..., s. 1.

88 Co słychać $w$ mieście?, PR, 1932, nr 1, s. 1.

89 Por. "Program żydowski” "Ziemi Rzeszowskiej”, PR, 1932, nr 8, s. 3; G. S prung, „O konkurencji żydowskiej”. „Ziemi Rzeszowskiej” w odpowiedzi, PR, 
periodyku, że jest to „Tutejsze miejscowe pisemko naszych domorosłych endeków [...]"90. Odrzucano ataki na niechrześcijański handel, tłumacząc, że niższe ceny w sklepach prowadzonych przez Żydów niż u katolickich konkurentów nie świadczą o gorszej jakości towaru ${ }^{91}$. Przekonywano, że „Żyd nie szuka nadmiernych zysków, tylko zadowalnia się zyskiem małym, który by mu umożliwił egzystencję i życie"92.

Na łamach „Przeglądu Rzeszowskiego” żywo opisywano lokalne żydowskie życie polityczne. Przedstawiano ujemnie ugrupowania Aguda i Machzike Hada ${ }^{93}$. Krytykowano partie działające w mieście za brak porozumienia, skłócenie między sobą ${ }^{94}$.

Liczne publikacje miały za temat funkcjonowanie rzeszowskiego kahału. Podkreślano, że w gminie panuje konfliktowa atmosfera. Zaznaczano, że „kahał już jest stworzony do wiecznej walki”" Relacjonowano przebieg rywalizacji o mandaty i wpływy, zarzucając części konkurentów o motywacje osobiste ${ }^{96}$. Pisano o zaniedbywaniu obowiązków służbowych przez urzędników kahalnych ${ }^{97}$. Tak jak w dwutygodniku z 1927 r. używano wobec kahału określenia „bagno”, „bagienko"98. W drugiej połowie czerwca, kiedy rozpoczą się sezon wakacyjny, $z$ ironia przekazywano czytelnikom wiadomość: „Nasz kahał rozpoczął już swój letni urlop i nie interesuje się już żadna sprawa, żadnym wydarzeniem [...]"99. Głoszono, że odpowiedzią na panujące stosunki winno być „Utworzenie jednolitego frontu wszystkich uczciwych i zdrowo myślących Żydów, mających na celu nie osobiste interesy i ambicyjki, tylko dobro ogółu żydowskiego [...]"100.

1932, nr 12, s. 3 (polemika podpisana: Gizela Sprung); O konkurencji żydowskiej. Wpadunek Ziemi Rzeszowskiej, PR, 1932, nr 14, s. 2.

90 „Program żydowski” „Ziemi Rzeszowskiej”..., s. 3.

${ }_{91}$ G. Sprung, op. cit., s. 3.

92 O konkurencji żydowskiej. Wpadunek Ziemi Rzeszowskiej..., s. 2.

93 Dobitny argument, PR, 1932, nr 12, s. 2; Lustracja w kahale, PR, 1932, nr 2, s. 1; Nowe stronnictwo (Machzike-Hadas), PR, 1932, nr 9, s. 1.

${ }^{94}$ Dobitny argument..., s. 2; Lustracja $w$ kahale..., s. 1.

95 I znowu kahat, PR, 1932, nr 3, s. 3. Por. Na marginesie sporu kahalnego, PR, 1932, nr 4, s. 2; Kahat na urlopie, PR, 1932, nr 14, s. 4; xy, Na dnie Żydostwa Rzeszowskiego. Włodarze..., PR, 1932, nr 5, s. 4.

${ }_{96}$ Zgromadzenie $w$ „Bikur - Cholim”, PR, 1932, nr 4, s. 3; Cisza przed burza, PR, 1932, nr 5, s. 1-2; Nowe stronnictwo..., s. 1.

97 Co słychać $w$ mieście?..., s. 1.

${ }_{98}$ Por. Z bagienka kahalnego, PR, 1932, nr 11, s. 2.

99 Kahat na urlopie..., s. 4.

100 Nowe stronnictwo..., s. 1. 
Zdawano sprawę $z$ przebiegu obrad organów kahału ${ }^{101}$. W dniu 25 marca informowano o kontroli odbywającej się w gminie żydowskiej ${ }^{102}$.

Dużym wydarzeniem w życiu rzeszowskich Żydów była śmierć wiceburmistrza Rzeszowa i zwierzchnika Komunalnej Kasy Oszczędności, dawnego zwierzchnika kahału, doktora Wilhelma Hochfelda. $\mathrm{W}$ artykule pośmiertnym przypomniano o zasługach zmarłego dla rodaków. Podkreślono, że ten dawny zwolennik asymilacji ludności żydowskiej odrzucił hasło polonizacji, któremu była niechętna redakcja „Przeglądu Rzeszowskiego”103.

Czasem pisano o świętach religijnych. Tak było np. przed Pesach $^{104}$. W okolicznościowym artykule krytykowano władze Wielkiej Brytanii za utrudnianie realizacji idei odbudowy państwa żydowskiego w Palestynie ${ }^{105}$.

W licznych publikacjach omawiano sprawy ekonomiczne, zdając relację $z$ kryzysowej sytuacji gospodarczej panującej na świecie i w Polsce. Podkreślano, że efektem kryzysu jest głód ${ }^{106}$. Analizowano zjawisko inflacji i deflacji ${ }^{107}$. Wypowiadano się $z$ obawą o groźbie zmniejszenia budżetu państwowego $\mathrm{RP}^{108}$ oraz o budżecie miejskim Rzeszowa ${ }^{109}$. Apelowano do władz państwa o obniżenie opłat za przewóz towarów pociagami ${ }^{110}$. Informowano o polityce finansowej i szerzej: gospodarczej, prowadzonej za granicą ${ }^{111}$. Dostrzegano

101 Z posiedzenia kahału, PR, 1932, nr 5, s. 2; Żałobne posiedzenie kahału, PR, 1932, nr 7, s. 1. Por. O memoriałach pana Dra Maksymiliana Wiesnera-słów kilka, PR, 1932, nr 7, s. 2 (artykuł na temat memoriałów M. Wiesnera, skierowanych do Ministerstwa Wyznań Religijnych i Oświecenia Publicznego i władz województwa lwowskiego, przedstawionych 17 IV 1932 r. „Na posiedzeniu Zarządu i Rady gminy wyznaniowej w Rzeszowie [...]”. Memoriały podejmowały temat stosunków panujacych w rzeszowskiej gminie żydowskiej, O memoriałach..., s. 2).

102 Lustracja w kahale..., s. 1.

${ }^{103}$ Błp. Dr Wilhelm Holchfeld, PR, 1932, nr 7, s. 1. Por. Żałobne posiedzenie kahatu..., s. 1.

104 O. Jare, Święto wyzwolenia, PR, 1932, nr 6, s. 1; S.S., Święto wolności i wyzwolenia, PR, 1932, nr 6, s. 4.

105 O. Jare, Święto..., s. 1.

$106 Z$ rozmyślań kryzysowych [cz. I], PR, 1932, nr 1, s. 3. Por. Z rozmyślań kryzysowych II, PR, 1932, nr 3, s. 3.

107 O. J a r e, Czy planowa inflacja potrafi zlikwidować kryzys?, PR, 1932, nr 2, s. 2.

108 W obliczu redukcji budżetu państwowego, PR, 1932, nr 10, s. 1.

109 Jak wyglada nasz budżet miejski na rok 1932/ 1933!, PR, 1932, nr 3, s. 1.

110 Konieczność zmiany taryfy kolejowej!, PR, 1932, nr 11, s. 2.

111 Co oznacza Goldburughs - Bill?, PR, 1932, nr 9, s. 3; Bimetalizm, PR, 1932, nr 12, s. 2; Polityka samowystarczalności!, PR, 1932, nr 1, s. 2. 
związek między problemami ekonomicznymi i politycznymi, pisząc o zagrożeniu hitleryzmem ${ }^{112}$. Dnia 8 kwietnia przybliżono czytelnikom zasady rozejmu celnego podpisanego między Polską a Niemca$\mathrm{mi}^{113}$. Odnoszono się do spraw związanych $\mathrm{z}$ wymiarem podatków, dając wyraz niepokojowi o los kupców ${ }^{114}$.

Wypowiadano się w obronie żydowskich handlarzy, prowadzących stragany na ulicy Kopernika w Rzeszowie, szykanowanych przez władze porządkowe. Podpowiadano rządzącym miastem, że „wskazanym by było, ażeby Magistrat pomyślał o urządzaniu hal targowych na wzór innych miast i ażeby tam skoncentrować cały handel dotychczas straganowy"115. Autor artykułu $z$ numeru piatego, podpisany O.J., wyraził pogląd o potrzebie wsparcia ze strony władz państwowych dla działalności handlowej116. W tym samym piśmie zwalczano przepisy o „przymusowym odpoczynku niedzielnym", niekorzystne dla kupców wyznania mojżeszowego ${ }^{117}$.

Broniono interesów rzemieślników, stwierdzając $z$ bólem to, że „Z próżnego [...] nie naleje" ${ }^{118}$. Starano się skłonić żydowskich kupców i rzemieślników do świadczenia sobie wzajemnej pomocy ${ }^{119}$.

W związu z sytuacją ekonomiczna drukowano artykuły dotyczące polityki socjalnej państwa i lokalnej działalności charytatywnej. Przypominano o środowiskach i instytucjach potrzebujacych pomocy ${ }^{120}$.

${ }^{112} Z$ rozmyślań kryzysowych [cz. I]..., s. 3. W czerwcu redakcja poparła wiec zorganizowany $\mathrm{w}$ rzeszowskim ratuszu jako wyraz poparcia rzeszowian dla polskiego stanowiska odnośnie do Gdańska, por. Wiec manifestacyjny $w$ sprawie Gdańska, PR, 1932, nr 14, s. 3.

113 (j.), Rozejm celny polsko-niemiecki, PR, 1932, nr 4, s. 2.

114 Przed wymiarem podatku przemysłowego za rok 1931, PR, 1932, nr 4, s. 1; Ulgi $w$ spłacie podatku przemysłowego, PR, 1932, nr 7, s. 3.

115 Por. Straganiarze..., s. 1-2.

116 O.J. [O. Jare?], Czy nareszcie pomoc dla kupiectwa?, PR, 1932, nr 5, s. 1.

117 Sprawa przymusowego odpoczynku niedzielnego, PR, 1932, nr 7, s. 3.

118 Fatalne położenie rzemieślników, a zwłaszcza żydowskich, PR, 1932, nr 15, s. 2.

119 Stosunki $w$ kupiectwie i rzemiośle żydowskim, PR, 1932, nr 14, s. 1.

120 Por. Z walnego zgromadzenia Towarzystwa Opieki nad Sierotami Żydowskimi $w$ Rzeszowie, PR, 1932, nr 4, s. 4; Tydzień Akademika Żydowskiego, PR, 1932, nr 4, s. 3; Z Tygodnia Akademika Żydowskiego, PR, 1932, nr 5, s. 3; Przed zgromadzeniem Ochronki, PR, 1932, nr 6, s. 3; Przed walnym zgromadzeniem Stowarzyszenia ku Utrzymaniu Starców Izraelickich $w$ Rzeszowie, PR, 1932, nr 6, s. 3; Z walnego zgromadzenia Ochronki Żydowskiej, PR, 1932, nr 8, s. 2; O szpital żydowski, PR, 1932, nr 9, s. 2; Tydzień sierocy, PR, 1932, nr 10, s. 3; Walne zgromadzenie Zwiazku Inwalidów Wojennych, PR, 1932, nr 10, s. 3; Z Urzędu Wojewódzkiego, PR, 1932, nr 9, s. 3 (informacja o działalności władz województwa lwowskiego w zakresie pomocy socjalnej bezrobotnym i ich dzieciom); Nie będzie zmian $w$ ustawodawstwie społecznym, PR, 1932, nr 14, s. 2. 
Odnoszono się również do złej sytuacji lokatorów, wynajmujących lokale ${ }^{121}$.

Omawiano także problemy szkolnictwa. Krytykowano program nauczania historii literatury polskiej i powszechnej jako zbyt mało rozbudowany oraz niewielką skuteczność nauczania języków obcych $^{122}$. Gorąco zachęcano rodziców, aby zapisywali dzieci nie do szkół państwowych, ale do żydowskich działających w Rzeszowie, zapewniających w przekonaniu redakcji edukację na wyższym poziomie ${ }^{123}$. Proszono ich: „Rodzice żydowscy! Mimo krytycznych warunków ekonomicznych, posyłajcie swe dzieci - dla ich dobra, które Wam droższe jest nad życie - do żydowskiego przedszkola i do szkoły. W waszym interesie leży doprowadzenie tej szkoły do rozkwitu. W waszym interesie leży umożliwienie rozkwitu gimnazjum żydowskiego [...]"124. W numerze 10 ogłoszono komunikat o zapisach do żydowskich szkół ludowej, średniej i zawodowej w Rzeszowie ${ }^{125}$.

Identycznie jak w dawniejszym żydowskim „Przeglądzie Rzeszowskim" zarzucano zarządzającym miastem, że za mało dbaja o czystość miasta oraz o stworzenie mieszkańcom odpowiednich warunków do wypoczynku i rekreacji ${ }^{126}$. Nawiąywano do propozycji, aby dostosować rzekę Wisłok do potrzeb wioślarstwa i sportu kajakowego. Dostrzegano potrzebę budowy stadionu, zorganizowania kapielisk i kina letniego. Wybudowanie w Rzeszowie basenu miało umożliwić rozwój sportu pływackiego. Proponowano, by stworzyć park na Lisiej Górze nad Wisłokiem i uatrakcyjnić lasek, również znajdujący się nad tą rzeką. Ławki na alei pod Kasztanami koło zamku Lubomirskich w centrum miasta uważano za niewystarczające w stosunku do istniejacych potrzeb rekreacyjnych $^{127}$. W notatce Zamiatanie ulic przypominano, że przed sprzątaniem należy skropić ulice woda, aby nie powodować tumanów kurzu zanieczyszczających ubrania przechodniów i „towary sklepowe" 128 .

121 Wiec właścicieli realności, PR, 1932, nr 15, s. 3.

122 U schyłku gimnazjum ośmioklasowego $w$ Polsce, PR, 1932, nr 2, s. 5.

123 Żydostwo wobec nowych stosunków w szkolnictwie, PR, 1932, nr 9, s. 2.

124 Co to jest „uspołecznienie dziecka”?, PR, 1932, nr 11, s. 1.

125 Komunikat, PR, 1932, nr 10, s. 3.

${ }^{126}$ Rzeszów w lecie, PR, 1932, nr 11, s. 3; Znasz ty ten gród, kędy Wisłok płynie?, PR, 1932, nr 14, s. 2; Znasz ty ten gród, kędy Wisłok płynie? (Dokończenie), PR, 1932, nr 15, s. 2.

127 Rzeszów w lecie..., s. 3.

${ }^{128}$ Kronika, PR, 1932, nr 11, s. 4. 
Stała rubryką była Kronika zawierajacca notatki o wydarzeniach $z$ życia Rzeszowa, czasem także $z$ regionu, choćby $z$ miasteczka Kolbuszowa. Ważne miejsce zajmowały wiadomości sensacyjne, przede wszystkim kryminalne. Nie brakowało aktualności kulturalnych i sportowych oraz o działalności charytatywnej, wiecach, demonstracjach politycznych i strajkach ${ }^{129}$. Wskazywano na lekceważenie przez magistrat swoich obowiązków. W notatce Dziury na ulicach miasta alarmowano: „Bruk przy ulicy Gałęzowskiego w kilku miejscach się zapadł, tworząc wielkie dziury, uniemożliwiające jazdę na tej ulicy. Stan ten trwa już kilka tygodni, a mimo to Magistratowi nie bardzo się spieszy z naprawą. Należałoby chociaż umieścić tablice ostrzegawcze lub ogrodzić dane miejsca, gdyż nietrudno tam o wypadki niebezpieczne"130.

Czasem opracowywano rubrykę $Z$ sali sąowej ${ }^{131}$. Częściej niż w dawniejszym „Przeglądzie Rzeszowskim” prezentowano korespondencje przysłane przez współpracowników z terenu. Materiały nadeszły $z$ Sokołowa Małopolskiego ${ }^{132}$, Strzyżowa ${ }^{133}$, Tyczyna ${ }^{134}$, Sędziszowa Małopolskiego ${ }^{135}$.

Redakcja zamieszczała listy od czytelników. Oprócz cytowanego listu od H.E. o łamaniu zasady tajemnicy korespondencji przez urzędników pocztowych i policjantów ${ }^{136}$ ogłosiła wypowiedź Hirscha Salzmana $z$ Tyczyna, będąca obroną zmarłego żydowskiego redaktora prasowego i działacza politycznego Markusa Salika ${ }^{137}$. Pragnąc

129 Kronika, PR, 1932, nr 1, s. 3-4; Kronika, PR, 1932, nr 2, s. 4; Kronika, PR, 1932, nr 3, s. 4; Kronika, PR, 1932, nr 4, s. 4; Kronika, PR, 1937, nr 5, s. 4; Kronika, PR, 1932, nr 8, s. 4; Kronika, PR, 1932, nr 9, s. 4; Kronika, PR, 1932, nr 11, s. 4; Kronika, PR, 1932, nr 12, s. 4; Kronika, PR, 1932, nr 14, s. 4; Kronika, PR, 1932, nr 15, s. 4.

130 Kronika, PR, 1932, nr 9, s. 4.

131 Ze sali sadowej, PR, 1932, nr 7, s. 4; Z sali sadowej, PR, 1932, nr 8, s. 4; Ze sali sądowej, PR, 1932, nr 12, s. 4; Ze sali sadowej, PR, 1932, nr 15, s. 4.

${ }_{132}$ Ab., Korespondencja $z$ Sokołowa, PR, 1932, nr 7, s. 4. Korespondent informował m.in., że „Na polu kulturalnego życia naszego miasta należy w pierwszym rzędzie nadmienić istnienie i rozwój biblioteki żydowskiej "Hatchiję", z której korzysta mnóstwo czytelników, należących do różnych kierunków politycznych”, ibidem.

133 Ze Strzyżowa, PR, 1932, nr 8, s. 3; Ze Strzyżowa, PR, 1932, nr 9, s. 4.

134 Z Tyczyna, PR, 1932, nr 8, s. 4.

135 Stosunki $w$ kahale $w$ Sędziszowie, PR, 1932, nr 12, s. 3; Od redakcji, PR, 1932, nr 14, s. 4.

136 Pod adresem poczty..., s. 4.

137 PR, 1932, nr 10, s. 3. Por. też inne listy do redakcji: PR, 1932, nr 12, s. 3 (dwa listy - od Dawida Perlberga i Gizeli Sprung); PR, 1932, nr 8, s. 2 (list w sprawie wysokości „opłat miejskich od ładunków kolejowych”). 
mieć stały kontakt $z$ odbiorcami, organizowała dyżury w swoim lokalu na Rynku ${ }^{138}$.

Redaktor Lubasz zaniedbywał zadanie lokalnego pisma, polegające na umożliwianiu odbiorców kontaktu $z$ satyra. W numerze trzecim znalazł się niewielki Kacik satyryczny ${ }^{139}$. Znacznie bardziej atrakcyjna lektura była Rzeszowska szopka polityczna z 20 maja, napisana wierszem na melodię Umark, Maciek umark, w której niepodpisany autor wyśmiewał stosunki panujące w kahale, zaczynajacc od zwrotki: „Stoi rebe, stoi / W ministerskiej sieni, / I wszelkie kahały / Chciałby mieć w kieszeni. / Kompetencja gminy cała. By rebemu geld dawała / Danaz, moja dana / Dana, dana" ${ }^{140}$. Zachętą do biernego uczestnictwa w kulturze miały być informacje o repertuarze kin Wanda, Muzeum i Henryka w Rzeszowie ${ }^{141}$.

Mniej regularnie w porównaniu z periodykiem Platzera i Frölicha popularyzowano sztukę teatralną. Omawiano jednak działalność Żydowskiego Towarzystwa Muzycznego i Dramatycznego w Rzeszowie, które w 1932 r. wznowiło działalność po czterech latach przerwy i zaczęło dawać przedstawienia amatorskie ${ }^{142}$. Informację o towarzystwie zamieszczono też w Kronice ${ }^{143}$. Chwalono teatr amatorski Scena. O jednej $z$ realizacji zespołu, widowisku Tanct - Jidałech - Tanzt!, napisano: "zaśmiała się i rozhulała się "Scena" wspaniała żydowska rewia" ${ }^{144}$. Do tego samego numeru trafiło hasło reklamowe: „Kto był i nie był wszyscy pójda na szlagierowa rewię "Sceny" w sobotę 30 kwietnia o godzinie 8.15 wieczorem w sali Domu Ludowego"145. Dnia 13 maja donoszono o koncercie recytatorki Ewy Zawirskiej i skrzypaczki Stelli Dortheimerównej, planowanym w rzeszowskim Domu Ludowym Bet-Am na 14 maja. Bilety były sprzedawane w redakcji „Przeglądu Rzeszowskiego” ${ }^{146}$.

138 Od redakcji, $\mathrm{PR}, 1932, \mathrm{nr} 5$, s. 4.

139 Kacik satyryczny, PR, 1932, nr 3, s. 2.

140 Rzeszowska szopka polityczna (śpiewać na nute „Umark Maciuś, umark...” ale po cichu), PR, 1932, nr 10, s. 4.

141 Co graja kina, PR, 1932, nr 1, s. 4; Co graja kina, PR, 1932, nr 2, s. 4; Co graja kina, PR, 1932, nr 3, s. 4.

142 Por. Mecenas Bolbec $i$ jego maż Beera $i$ Verneuilla, PR, 1932, nr 1, s. 3 (recenzja $z$ nagłówkiem Ze sceny $i$ estrady). Por. też O pracę Żydowskiego Towarzystwa Muzycznego i Dramatycznego, PR, 1932, nr 15, s. 3.

${ }_{143}$ Por. Kronika, PR, 1932, nr 3, s. 4 (notatka pt. ZZŻydowskiego Towarzystwa Muzycznego i Dramatycznego).

144 Tanct jidałech tanct, PR, 1932, nr 7, s. 4. Por. reklamy tej rewii: PR, 1932, nr 4, s. 4; PR, 1932, nr 5, s. 2.

${ }_{145}$ PR, 1932, nr 7, s. 4 (hasło reklamowe wydrukowane u góry strony na cała jej szerokość).

${ }^{146}$ Kronika, PR, 1932, nr 9, s. 4. 
W czasopiśmie reklamowano występy objazdowego teatru rewiowego Wesoły Amor, występującego na Placu Wolności w centrum miasta. Recenzent, podpisany kryptonimem (h), chwalił rewię Pod bandera humoru i zachęcał widzów do odwiedzenia teatrzyku ${ }^{147}$.

W dniu 8 kwietnia namawiano odbiorców gazety do zwiedzenia wystawy grafika i malarza Stanisława Jakubowskiego, której otwarcie zostało zapowiedziane na 10 kwietnia w Muzeum Towarzystwa Przemysłowego w Rzeszowie ${ }^{148}$.

Samuel Lubasz przykładał dużą wagę do promocji literatury pięknej. Na okoliczność setnej rocznicy śmierci Johanna Wolfganga Goethego, mijającej 22 marca 1932 r., opublikował artykuł o inspiracjach filozofią i religia żydowska, widocznych w twórczości niemieckiego pisarza ${ }^{149}$. W innym artykule oceniono bardzo wysoko dorobek amerykańskiego powieściopisarza Theodore'a Dreisera, utożsamiając się $z$ „walką o prawa człowieka”, prowadzona przez autora ${ }^{150}$. Na pochwałę zasługiwało drukowanie utworów prozą autorstwa Izaaka Lejba Pereca ${ }^{151}$, Jerzego Clemenceau ${ }^{152}$ i Szolema Alejchema ${ }^{153}$. Opowiadania Clemenceau i Alejchema miały tematykę żydowską.

W tygodniku w niewielkim stopniu upowszechniano wiedzę historyczną. Wyjątkiem był artykuł doktora Mojżesza Altera, zajmujacy prawie cała stronę numeru piatego ${ }^{154}$. Reklamowano także wykład Altera Rabini rzeszowscy $w$ XVII $i$ XVIII wieku, zapowiedziany na

147 (h.), „Wesoły Amor”, PR, 1932, nr 6, s. 4. Por. reklamę występów Wesołego Amora, które rozpoczęły się w Rzeszowie w sobotę 16 kwietnia: PR, 1932, nr 5, s. 4. Por. też notatkę Wesoły Amor, będącą zapowiedzią tych występów: Kronika, PR, 1932, nr 4, s. 4.

${ }^{148}$ OPAL, Wystawa laureata nagrody Polskiej Akademii Umiejętności prof. S. Jakubowskiego $w$ Rzeszowie, PR, 1932, nr 4, s. 3.

149 Por. Fr., Goethe a żydostwo, PR, 1932, nr 1, s. 2.

150 Ameryka w świetle twórczości Dreisera, PR, 1932, nr 14, s. 3.

151 I.L. Pe re c, Księżyc opowiada, przełożył L. Herbst, PR, 1932, nr 1, s. 2-3.

152 J. Cle me nceau, Szloma żołnierz [odcinek 1], przełożył Leonha, PR, 1932, nr 2, s. 2; id e m, Szloma żołnierz 2 [odcinek 2], przełożył Leonha, PR, 1932, nr 3, s. 2; id e m, Szloma żołnierz 3 [odcinek 3], przełożył Leonha, PR, 1932, nr 4, s. 2; id e m, Szloma żołnierz 4 [odcinek 4], przełożył Leonha, PR, 1932, nr 5, s. 2.

153 S. Alejchem, Niebezpieczna maca, przełożył L. Herbst, PR, 1932, nr 6, s. 3-4; ide m, Tramwaj w Kasrilewce [odcinek 1], przełożył L. Herbst, PR, 1932, nr 10, s. 2 (opowiadanie, opublikowane „W 16-ta rocznice zgonu Twórcy”, zmarłego w 1916 r., o czym informowano w nagłówku); i d e m, Tramwaj w Kasrilewce 2 [odcinek 2], przełożył L. Herbst, PR, 1932, nr 11, s. 2; i d e m, Tramwaj w Kasrilewce 3 [odcinek 3], przełożył L. Herbst, PR, 1932, nr 12, s. 2.

${ }^{154}$ M. Al t e r, Rezultat wizytacji biskupa przemyskiego Sierakowskiego w gminie żydowskiej w Rzeszowie $w$ roku 1746, PR, 1932, nr 6, s. 2. 
30 kwietnia 1932. Słuchaczy zapraszano do lokalu miejscowej organizacji syjonistycznej ${ }^{155}$.

Redakcja promowała działalność sportową. Na stronie pierwszej numeru z 25 marca pisano o żydowskiej imprezie sportowej, mającej się odbyć 29 marca w Tel Awiwie ${ }^{156}$. W rubryce Ze sportu informowano o występach i wynikach sportowców żydowskich $z$ Rzeszowa, Jasła, Lwowa, Jarosławia. Pisano o ping-pongu i piłce nożnej ${ }^{157}$. Promowano też hippikę ${ }^{158}$, lekkoatletykę i siatkówkę ${ }^{159}$. W przywołanych notatkach pisano także o polskich uczestnikach rywalizacji sportowych. „Przegląd Rzeszowski” popierał zbiórki pieniędzy na dofinansowanie działań w zakresie wychowania fizycznego młodzieży żydowskiej ${ }^{160}$. W piśmie popularyzowano działalność rzeszowskiego Żydowskiego Towarzystwa Gimnastycznego i Sportowego ${ }^{161}$.

Czytelnicy chętnie zapoznawali się $z$ nekrologami i kondolencjami, trafiajacymi do rubryki $Z$ kroniki żałobnej162. Zainteresowanie wzbudzały także gratulacje na okoliczność ślubu ${ }^{163}$ czy zaręczyn ${ }^{164}$ oraz ogłoszenia ${ }^{165}$.

155 PR, 1932, nr 7, s. 4

156 Makkabiada, PR, 1932, nr 2, s. 1.

157 Ze sportu, PR, 1932, nr 3, s. 4; Ze sportu, PR, 1932, nr 9, s. 3-4; Ze sportu, PR, 1932, nr 10, s. 4; Ze sportu, PR, 1932, nr 11, s. 4; Ze sportu, PR, 1932, nr 12, s. 4; Ze sportu, PR, 1932, nr 14, s. 4.

158 Ze sportu, PR, 1932, nr 9, s. 3-4.

159 Ze sportu, PR, 1932, nr 14, s. 4.

160 Por. np. Fundusz łańcuchowy, PR, 1932, nr 15, s. 4 (notatka o datkach na fundusz).

${ }^{161}$ Kronika, PR, 1932, nr 1, s. 3-4 (notatka Z Żydowskiego Towarzystwa Gimnastycznego i Sportowego $w$ Rzeszowie).

162 Z kroniki żałobnej, PR, 1932, nr 1, s. 3; Z kroniki żałobnej, PR, 1932, nr 3, s. 4; $Z$ kroniki żałobnej, PR, 1932, nr 6, s. 4; Z kroniki żałobnej, PR, 1932, nr 10, s. 4; Z kroniki żałobnej, PR, 1932, nr 11, s. 4; Z kroniki żałobnej, PR, 1932, nr 12, s. 4. Por. Btp. Hirsch Wistreich, PR, 1932, nr 15, s. 3 (wspomnienie pośmiertne i sprawozdanie $z$ pogrzebu). Na tej samej stronie: „kondolencje dla członka Żydowskiego Towarzystwa Dramatycznego Scena, E. Lamównej, przysłane do redakcji przez towarzystwo na okoliczność śmierci jej ojca”, PR, 1932, nr 15, s. 3.

163 Por. PR, 1932, nr 5, s. 3.

164 PR, 1932, nr 9, s. 3.

$165 \mathrm{~W}$ jednym $z$ ogłoszeń ostrzegano np. przed kupowaniem weksli pozostających w obiegu, ale nieważnych, PR, 1932, nr 7, s. 4. W innym proszono o pomoc na rzecz mieszkańca miasta: „Mojżesz Feit z Rzeszowa, Nowe Miasto, zgubił portfel $z$ wekslami. Uprasza się o zwrot za wynagrodzeniem", PR, 1932, nr 8, s. 3 . Inny czytelnik poszukiwał mieszkania w centrum Rzeszowa, na ulicy Kościuszki, 3 Maja lub Grunwaldzkiej, PR, 1932, nr 9, s. 4. 
Do „Przeglądu Rzeszowskiego” z 1932 r. napływało niedużo reklam, co wynikało $z$ trudnej sytuacji większości firm, $z$ małego zbytu towarów oraz usług w czasie kryzysu. Nie zajmowały całej ostatniej strony i czasem części innych stron, jak w 1927 r., ale zamieszczano je sporadycznie między tekstami ${ }^{166}$. Działo się tak mimo drukowania w periodyku hasła „Reklama dźwignią handlu!”, mającego przyciagnać reklamodawców"167.

Krótko przed likwidacja pisma podkreślano złą sytuację finansową periodyku. Przypominano czytelnikom: „Uprasza się P.T. Prenumeratorów o wyrównywanie zaległości”"168. W numerze 15 apelowano do prenumeratorów spoza Rzeszowa o zapłacenie należnych pieniędzy „celem uniknięcia przerwy w wysyłce gazety" ${ }^{169}$. Złe położenie finansowe redakcji i czytelników spowodowało, że był to ostatni numer tygodnika.

Obydwa żydowskie „Przeglądy Rzeszowskie” drukowano w drukarni Mojżesza Goldberga, funkcjonującej w Rzeszowie ${ }^{170}$ od początku XX w. do 1939 r. ${ }^{171}$

W 1939 r. wychodził równie efemeryczny, polski tygodnik „Przegląd Rzeszowski”, mający skrajnie odmienne oblicze polityczne niż pisma z 1927 i 1932 r., jako organ prasowy Obozu Zjednoczenia Narodowego ${ }^{172}$.

"Przegląd Rzeszowski” z 1927 i 1932 r. zawiera cenne wiadomości o życiu społecznym w Rzeszowie i w znacznie mniejszym stopniu w okolicach miasta w okresie II RP. Redakcje starały się osiagnąć

\footnotetext{
166 Por. PR, 1932, nr 1-12, 14-15

167 Por. PR, 1932, nr 2, s. 4; nr 3, s. 2; nr 12, s. 2.

168 Kronika, PR, 1932, nr 12, s. 4.

169 Kronika, PR, 1932, nr 15, s. 4.
}

170 S. Darłakowa, Prasa Rzeszowa..., s. 42; e a d e m, Czasopiśmiennictwo i prasa.., s. 238; A. Jagusztyn, op. cit., s. 94-95. Por. PR, 1927, nr 1, 9-16; 1932, nr 1-12, 14-15 (informacja o drukarzu - na dole s. 4, czyli ostatniej strony numerów).

171 A. Jagu szty n, op. cit., s. 72, 94-95, 98-99, 104-105, 108, 114-117; i d e m, Drukarstwo, ksiegarstwo i biblioteki, [w:] Dzieje Rzeszowa..., s. 248-250; id em, Bibliografia druków tłoczonych $w$ drukarniach Rzeszowa w latach 1843-1939, Rzeszów 1973, s. 192-196 (rozdział Drukarnia Mojżesza Goldberga); J. Petrus, Stosunki gospodarcze, [w:] Dzieje Rzeszowa..., s. 64; A. Potocki, Stownik biograficzny Żydów z Podkarpackiego, Rzeszów 2010, s. 96 (hasło Goldberg Mojżesz, drukarz); M. Kału ski, Ku pamięci i w podzięce Jankielom. Mały leksykon Żydów - patriotów polskich, Warszawa 2001, s. 54 (hasło Goldberg Mojżesz (XIX-XX w.), drukarz). Jan Grygiel w artykule popularnonaukowym poświęconym dziejom prasy w Rzeszowie podał błędnie, że drukarnia Goldberga powstała pod koniec XIX w., por. J.G. [J. Grygie1], $Z$ historii prasy $w$ Rzeszowie, „Widnokrag. Tygodnik Kulturalny" 1966, nr 23, s. 2.

172 S. Darłakowa, Prasa Rzeszowa..., s. 47-48. 
wielotematyczność oraz stosować różne formy wypowiedzi dziennikarskiej. Zasługuja na uznanie za próbę stworzenia czasopism niezależnych, niezwiąanych $z$ konkretnym obozem politycznym. Imponuje odważny krytycyzm wobec lokalnych polityków i gminy żydowskiej. Autorzy, pisząc na temat zagadnień związanych $z$ higiena i estetyka miasta, a także potrzeby zapewnienia mieszkańcom odpowiednich warunków do wypoczynku, wykazywali troskę o rzeszowian różnych narodowości. Rozumieli związek między światowa i ogólnopolską sytuacja polityczną oraz gospodarczą a problemami lokalnymi czy regionalnymi. Ciężkie położenie ekonomiczne czytelników i obu redakcji spowodowało, że pisma nie mogły się rozwinąć i dłużej współtworzyć tradycji prasy lokalnej w RP.

\section{Bibliografia}

\section{Prasa}

„Przegląd Rzeszowski” 1927, nr 1, 9-15.

„Przegląd Rzeszowski” 1932, nr 1-12, 14-15.

\section{OpRacowania}

Bonusiak W., Stosunki ludnościowe, [w:] Dzieje Rzeszowa, t. III (Rzeszów w okresie międzywojennym i okupacji [1918-1944]), red. F. Kiryk, Rzeszów 2001, s. 89-102.

Darłakowa S., Czasopiśmiennictwo i prasa, [w:] Dzieje Rzeszowa, t. III (Rzeszów $w$ okresie międzywojennym i okupacji [1918-1944]), red. F. Kiryk, Rzeszów 2001, s. 229-244.

Darłakowa S., Prasa Rzeszowa XIX i XX wieku, Rzeszów 1966.

J.G. [J. Grygiel], Z historii prasy w Rzeszowie, „Widnokrag. Tygodnik Kulturalny” 1966, nr 23, s. 2.

Jagusztyn A., Bibliografia druków tłoczonych $w$ drukarniach Rzeszowa w latach 1843-1939, Rzeszów 1973.

Jagusztyn A., Drukarstwo, ksiegarstwo i biblioteki, [w:] Dzieje Rzeszowa, t. III (Rzeszów $w$ okresie międzywojennym i okupacji [1918-1944]), red. F. Kiryk, Rzeszów 2001, s. 245-256.

Jagusztyn A., Dzieje drukarstwa i ksiegarstwa $w$ Rzeszowie $w$ latach 1840-1939, Rzeszów 1974.

Kałuski M., Ku pamięci i w podzięce Jankielom. Mały leksykon Żydów - patriotów polskich, Warszawa 2001, s. 54 (hasło Goldberg Mojżesz [XIX-XX w.], drukarz). 
Ożóg M.E., Środowisko żydowskie, [w:] Dzieje Rzeszowa, t. III (Rzeszów w okresie międzywojennym i okupacji [1918-1944]), red. F. Kiryk, Rzeszów 2001, s. 517-539.

Petrus J., Stosunki gospodarcze, [w:] Dzieje Rzeszowa, t. III (Rzeszów w okresie międzywojennym i okupacji [1918-1944]), red. F. Kiryk, Rzeszów 2001, s. 53-87.

Potocki A., Słownik biograficzny Żydów z Podkarpackiego, Rzeszów 2010, s. 96 (hasło Goldberg Mojżesz, drukarz).

Potocki A., Żydzi w Podkarpackiem, Rzeszów 2004.

Wierzbieniec W., Stosunki wyznaniowe, [w:] Dzieje Rzeszowa, t. III (Rzeszów $w$ okresie międzywojennym i okupacji [1918-1944]), red. F. Kiryk, Rzeszów 2001, s. 401-476.

Wierzbieniec W., Żydzi w województwie lwowskim $w$ okresie międzywojennym. Zagadnienia demograficzne i społeczne, Rzeszów 2003.

Wierzbieniec W., Żydzi rzeszowscy, [w:] Encyklopedia Rzeszowa, red. J. Draus, Rzeszów 2004, s. 820-828.

Wierzbieniec W., Żydzi rzeszowscy, [w:] Encyklopedia Rzeszowa, red. J. Draus, G. Zamoyski, Rzeszów 2011, s. 1018-1025.

Adrian UlJasz

\section{A study into the local press of the Second Polish Republic The Jewish „Przegląd Rzeszowski” of 1927 and 1932}

Przegląd Rzeszowski" was a title of two different jewish periodicals published "I in Polish and issued in Rzeszów. The first "Przegląd Rzeszowski” was a biweekly, published in 1927, and its editors were C.L. Plattzer and M.M. Fröchlich. The second "Przegląd Rzeszowski”, from 1932 was a weekly - its editor-in-chief was Samuel Lubasz.

Both periodicals dealt with economical, social and political issues concerning Jews, provided information about events in the town and its region and promoted Jewish cultural and sport life. The also featured advertisements.

Keywords: „Przegląd Rzeszowski” 1927, „Przegląd Rzeszowski” 1932, press history, Jews history, Rzeszów history. 